\title{
Communication Technician: One of the Roles of Yehonala School Public Relations in Maintaining Image
}

Andy $^{1}$, and Angel Purwanti ${ }^{2}$

${ }^{1,2}$ Universitas Putera Batam, Batam, Indonesia

\begin{abstract}
School is one of the institutions in transferring the balance between moral values to students in the learning process, so as to create innovations to improve the quality of institutions nationally. Yehonala School, one of the schools in Batam City that focuses on developing and shaping the characteristics of educators. Yehonala School is a National Plus based school in partnership with Cambridge University Press, and the motto is 'To Grow in Wisdom!' starting from the Play Group level, Elementary School (SD), Junior High School (SMP), High School (SMA) and Vocational High School (SMK). Yehonala School has an image as "The Best Learning Place for Children", the image is obtained through superior programs and achievements obtained from the Indonesia Achievement Center (IAC). The image that has been formed and attached to the Yehonala school in Batam City. This, of course, cannot be separated from the role of Yehonala School's Public Relations in maintaining that image first during the current pandemic. This research is based on an analysis of systems theory and the concept of the four roles of Public Relations proposed by Cutlip, Center and Broom. The type of research applied in this research is descriptive qualitative, the data collection applied in this research is in-depth interviews. The analytical method applied in this research is the Miles and Huberman analysis technique called the interactive model. The purpose of this study was to find out how the role of PR as a communication technician in maintaining an image during a pandemic. The results of the study found that three coding findings related to the role of Yehonala School's Public Relations as a communication technician, namely: (1) Utilization of Social Media (2) Social Media Content (3) The resulting reaction. The role of Yehonala school's PR is only as a communication technician and Yehonala's school implements a closed system because PR does not act as an information seeker.
\end{abstract}

Keywords: School PR; Communication Technician; Education; Covid19; Batam

\section{Teknisi Komunikasi Salah Satu Peran Public Relations Sekolah Yehonala Batam Dalam Mempertahankan Citra}

\begin{abstract}
ABSTRAK
Sekolah merupakan salah satu institusi dalam mengtransfer kesimbangan antara nilai moral kepada siswa dalam proses pembelajaran, sehingga dituntut untuk melakukan inovasi-inovasi untuk meningkatkan mutu kelembagaan secara nasional. Sekolah Yehonala, salah satu sekolah di Kota Batam yang fokus dengan pengembangan dan pembentukan karakteritik pendidik. Sekolah Yehonala adalah sekolah yang berbasis Nasional Plus yang berkerja sama dengan Cambridge University Press, dan motto 'To Grow in Wisdom!' Dimulai dari tingkat Play Group, Sekolah Dasar (SD), Sekolah Menengah Pertama (SMP), Sekolah Menengah Atas (SMA) dan Sekolah Menengah Kejuruan (SMK). Sekolah Yehonala memiliki citra sebagai "The Best Learning Place for Children", citra didapatkan melalui program-program unggulan dan prestasi yang didapatkan dari Indonesia Achievement Center (IAC). Citra yang sudah terbentuk dan melekat pada sekolah Yehonala di Kota Batam. Hal ini tentunya tidak lepas dari peran Public Relations sekolah Yehonala dalam mempertahankan citra tersebut terlebih lagi
\end{abstract}


pada masa pandemi seperti sekarang ini. Penelitian ini dianalisis berdasarkan pada teori sistem dan konsep empat peran Public Relations yang dikemukakan oleh Cutlip, Centre dan Broom. Jenis penelitian yang diterapkan pada penelitian ini ialah kualitatif deskriptif, teknik pengumpulan data yang diterapkan dalam penelitan ini adalah adalah wawancara mendalam. Metode Analisis yang diterapkan pada penelitian ini ialah teknik analisis Miles dan Huberman yang disebut dengan interactive model. Tujuan penelitian ini adalah untuk mengetahui bagaimana peran PR sebagai teknisi komunikasi dalam mempertahankan citra pada masa pandemi. Hasil dari penelitian menemukan bahwa tiga pengkodean selektif temuan yang berkaitan dengan peran Public Relations sekolah Yehonala sebagai teknisi komunikasi yaitu: (1) Pemanfaatan Media Sosial (2) Konten Media Sosial (3) Reaksi yang dihasilkan. Peranan PR sekolah Yehonala hanya sebagai teknisi komunikasi dan sekolah Yehonala menerapkan sistem tertutup dikarenakan PR tidak berperan sebagai pencari informasi.

Kata kunci: HUMAS Sekolah; Teknikisi Komunikasi; Pendidikan; Covid-19; Batam

\section{INTRODUCTION}

Schools are one of the institutions in transferring the balance between moral values to students in the learning process, so they are required to make innovations to improve the quality of institutions nationally. Therefore, every school must have educational programs that prioritize the development and formation of educator characteristics (Satria et al., 2019). Yehonala School, one of the schools in Batam City that focuses on developing and shaping the characteristics of educators. Yehonala School is a National Plus-based school in collaboration with Cambridge University Press, and the motto 'To Grow in Wisdom!' Starting from the Play Group, Elementary School (SD), Junior High School (SMP), High School (SMA) level. and Vocational High School (SMK). In 2015, Yehonala School received an award as "The Best Learning Place for Children" from the Indonesia Achievement Center (IAC) with several criteria (1) the best favorite school for excellence in education quality in 2015 (2) the best education and guidance program in 2016 ( 3) Indonesia's leading education school award in 2017 (4) favorite school in terms of quality of education in 2019.

The program that makes Yehonala School "The Best Learning Place for Children" is the 4P program. The 4P program consists of (1) Tri-Language Program, namely applying Indonesian, English and Mandarin (2) Achievement Program, namely every student from kindergarten, elementary, junior high $\&$ high school who achieves first, second \& third rank in the class will get scholarships of 25\%, 50\% and 100\% (3) One-time Registration Program, where students only pay a one-time registration fee at the beginning (4) The Yehonala Family Program, namely siblings in one student's Family Card, is free of registration fees. Apart from the 4P program, there are additional programs, namely the Free Trial Class program for the public who want to know how teaching and learning activities are carried out in class and the 3 Years Pandemic Recovery Program (2022-2025). The Free Trial Class program is only specifically for prospective students aged 2 to 5 years or equivalent to Playgroup and Kindergarten classes. While the 3 Years Pandemic Recovery (2022-2025) program is a program to improve the economic stability of parents of students, namely with no price increases for three years and new students will get benefits such as five swimming class meetings presented by Swimming Studios who have worked the same as Yehonala School, one month free tutoring for reading 
and writing arithmetic (Calistung) only for pre-school and elementary school students and one month free English tutoring for junior and senior high school students.

"The Best Learning Place for Children" is an image that has been formed and is attached to Yehonala School in Batam City. This certainly cannot be separated from the role of Yehonala School's Public Relations in maintaining that image. The role of Public Relations is very important for institutional development, including educational institutions, namely elementary schools to universities. According to Rex Harlow, Senior Practitioners and Academics said that Public Relations has a special management function that focuses on efforts to develop relationships through communication activities including building understanding, acceptance and good cooperation between organizations and their publics.

Cutlip, Center and Broom explained that there are four Public Relations roles, namely (1) expert advisor, a Public Relations officer who acts as a consultant responsible for analyzing corporate cases, designing and being responsible for the application of Public Relations programs in the company (2) communication facilitator, a Public Relations role as a provider of news related to the company to be disseminated to stakeholders or the public. A Public Relations who acts as a communication facilitator also functions as a liaison, translator and as an intermediary between the company and the public (3) problem-solving facilitator, Public Relations practitioners do team work with internal management where they work to resolve cases related to communication corporations with a corporate life cycle (4) communication technician, a Public Relations practitioner in charge of carrying out orders from superiors to write articles, edit press releases, launch official websites and issue annual reports, design speeches and various other technical jobs (Dida et al. , 2017).

Based on direct observations, Yehonala School Public Relations utilizes social media in fostering good relations with the public and informing Yehonala school activities and promotions, especially during the current pandemic. Social media that is handled actively and appropriately will make changes to the increasing number of new students or students who register at the school because of the provision of clear information and through social media the school can show the achievements that have been obtained by the educational institution. (Wahyuni \& Ernungtyas, 2020). Social media managed by Yehonala School Public Relations include WhatsApp, Facebook, Youtube and Instagram. Social media is media in a network that supports social interaction (Doni, 2017). Social media provides a lot of convenience for its users because it is easily accessible using smart devices (smartphones) and anytime that is connected to the internet (Kemp, 2021).

The use of social media has changed the communication and public relations activities of an organization. Communication strategies, continuous monitoring, responsibility, from experts to update social media information, create content that provides relevant information to the public with acceptable quality (Wahyuni \& Ernungtyas, 2020). Yehonala school public relations provides information in the form of content consisting of videos, posters about programs that support the Yehonala school and are responsive in replying to messages or interacting with their followers. The role of Public Relations in educational institutions is no 
different from non-educational institutions because basically Public Relations is needed to build a positive image (Pohan, 2018). Another role of Public Relations is to publish schools, with the aim of building trust and conveying information (Ardianto, 2018).

A Public Relations can play a lot in developing the organization, of course, it is supported by various parties, besides that it is also supported by a good strategy and organizational system. Kowalski said that one of the strategic steps that can be implemented in improving the quality of school education is through the role of Public Relations. et al., 2019).

During the current pandemic, the role of a Public Relations practitioner in the world of education is no less important than non-educational institutions because the competition to introduce educational institutions is increasingly intense (Mahfuzhah \& Anshari, 2018). Almost all schools, especially private schools, introduce their educational institutions and maintain an image using social media, electronic media and print media to reach their target audience during the current pandemic. Based on the description above, the purpose of this study is to describe the role of Yehonala School's Public Relations in maintaining the image that has been built so far as "The Best Learning Place for Children" especially during the current pandemic which is focused on the social media used.

\section{METHODS}

The type of research applied in this research is descriptive qualitative, because this study intends to describe existing phenomena by analyzing and presenting data systematically to facilitate understanding for drawing conclusions (Purwanti, 2018). This study was analyzed using systems theory and the concept of the role of PR according to Cutlip, Center and Broom. In this study, it is more focused on how the role of the Yehonala School Public Relations practitioner as a communication technician in maintaining an image during the pandemic.

In selecting sources or informants, the authors apply purposive sampling technique. The purposive sampling technique is to concentrate on people with certain characteristics who will be better able to assist in relevant research (Etikan, 2016). The choice of this technique is because the researcher has determined the right informant or resource person to provide information in this study. The informants or informants in this study were the first informant: Mr. Chrysto Naru Kusumo (CNK) as the Yehonala School Public Relations practitioner, the second informant: Mr. Mori Ade Mulyandi (MAM) as the Head of Multimedia of Yehonala School and the third informant: Mrs. Lucy Desmilia (LD) as Head of Education.

Data collection techniques in this study apply three techniques, namely (1) interviews, in this study researchers apply in-depth interviews because researchers conduct interviews continuously and in depth to explore information from respondents (Kriyantono, 2014) (2) documentation, application of techniques This is because data collection is obtained through non-human sources (Suwendra, 2018). The documentation used by the researcher is documentation that belongs to the Yehonala school in the form of digital reports, printed reports and photos of activities (3) observation, this study applies non-participant observation techniques. Non-participant observations explained that the researcher only played the role of 
a spectator and not an actor (Ardianto, 2018). Observation activities are very important when a researcher still does not receive adequate information about the problem being studied (Mania, 2008). The interview data collection applied semi-structured and unstructured interview techniques to PR practitioners Mr. CNK, Head of Multimedia Mr. MAM and Head of Education Ms. LD.

The analytical method applied in this study is the Miles and Huberman analysis technique called the interactive model, namely qualitative data analysis with (1) data collection, leading to the results of interviews, observations and documents in the field (2) data reduction, leads to the process of selecting, focusing, simplifying, abstracting and changing the data that appears in the field. When processing the data obtained, it appears coding, summarizing and making groupings. (3) presentation of data, a collection of grouped and compressed information that allows conclusions and actions to be drawn (4) drawing conclusions or verification, a qualitative researcher starting from data collection has begun to determine the intent and description of the findings in the field but a competent researcher will hold light conclusions and maintain openness but conclusions remain that are initially unclear and vague become increasingly clear (Miles \& Huberman, 1994). Primary data was obtained from interviews with three key informants consisting of three people, namely Mr. CNK as a Public Relations practitioner, Mr. MAM as Head of Multimedia and Ms. LD while secondary data was obtained through the Instagram account @yehocircle.

\section{RESULT AND DISCUSSION}

Researchers got several findings that describe the role of Yehonala School's Public Relations in maintaining the image that has been built so far as "The Best Learning Place for Children" especially during the current pandemic. From the results of interviews, observations and documentation. Based on the results of interviews with the three informants, two of them are managers of social media publications in the school. Based on the research that has been done, there are three selective coding of findings related to the role of Yehonala School's Public Relations as a communication technician, namely: (1) Utilization of Social Media (2) Social Media Content (3) The resulting reaction.

\section{Social Media Utilization}

The role of Public Relations in building and maintaining the image of the Yehonala school by utilizing existing social media. The social media was created with the aim of keeping in touch with stakeholders such as students, parents, prospective students and the people of Batam City. Based on joint interview data, the two informants said that there were 4 (four) social media used, namely WhatsApp, Facebook, Instagram and Youtube, also according to observations made by researchers. The four Yehonala school social media are managed by the first informant $(\mathrm{CNK})$ and the second informant (MAM). Information was obtained from the first informant: "The four social media are me and Mr. Mori who manage the content". This statement was confirmed by the second informant (MAM) who said: "Before we were three people, me and then Mr. Chrysto, then there was one more person. Only now it's out because of this pandemic, so it's just the two of us." 
The use of social media by Yehonala school PR practitioners has been started since 2010 but the type used is only Facebook, for Instagram starting in 2014 while Youtube has started since 2016. It's been a long time, starting in 2010, Youtube starting in 2016 and Instagram in 2014." Although Instagram has been used since 2014 but the social media was really actively used in 2019 during the transition period to the new Yehonala school building, the second informant (MAM) stated: "It has been more intense since there was a new building, 2019."

However, of the four social media, Instagram is the most frequently used social media, because its use is easy and fast, especially during a pandemic like today. This was confirmed by the first informant (CNK). As a school PR practitioner, Yehonala stated “... Instagram is more trending right now, people are looking at Instagram a lot, starting from mothers, gentlemen, all of them play Instagram... Especially now, right? We collaborate with Instagram artists, celebrities and coincidentally, celebgram children go to school here too."

The second informant (MAM) also gave a similar answer, namely "Instagram is now more popular, and its use is easier and more user friendly compared to others." Previous research conducted by Ayu Andira Rasyid also said that Instagram is the most widely used social media and is considered the most effective as a means of promotion on the internet (Rasyid \& Purwanti, 2020).

The @yehocircle account is active almost 24 hours a day throughout the day including outside business hours. The information was obtained from the first informant (CNK) who said: "Almost 24 hours, as long as you pay attention to social media because notifications sometimes don't sound.". In contrast to the first informant, the second informant (MAM) said: "In terms of operations, we will adjust the working hours. From nine in the morning until four at five, but because of this pandemic until three o'clock. But if you want to reply to comments, DM us, we are free.". Researchers found different things during observations, the @ yehocircle account still uploads stories and updates its account on days and outside working hours. For information, Yehonala school operating hours on Monday to Friday start at 07.30 to 16.00 WIB while on Saturday it starts at 07.30 to 15.00 WIB.

\section{Figure 1. Instagram Yehonala School}

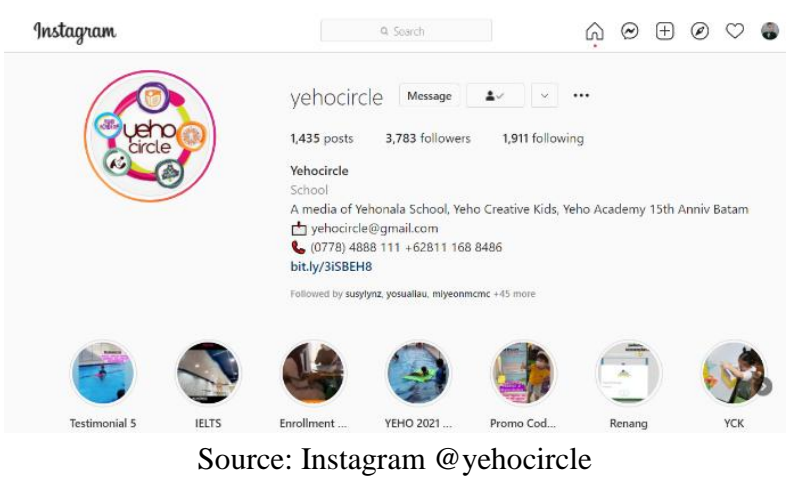

The social media is used to convey information about yehonala school programs, such as teaching and learning activities, training, competitions, extracurricular activities and promotion of new student admissions. As stated by the third informant (LD) stated: "This social media is used to provide information on activities, programs, and school promotions only". If the public 
wants to get clearer information about the program or promotion, the PR practitioner will send a message (DM) to the Instagram user account asking the question then the PR practitioner will ask for a WhatsApp number to be given to the marketing party to be contacted immediately and explain, this information was obtained from the informant first (CNK): "Only Whatsapp because marketing already knows about the price. As previously stated, if there are parents who ask questions on social media, we immediately ask for their WhatsApp number so that marketing can contact them immediately."

\section{Social Media Content}

Instagram content is a variety of things that users share through Instagram accounts (Febbyana, 2017). The @yehocircle account has a way of managing content on its social media as a medium to maintain its image. The content created by the school's Public Relations in the official Yehonala school Instagram account, in addition to containing information about Yehonala school programs and innovations in the teaching and learning process, also provides content regarding education, online teaching and learning activities and general knowledge. This information was confirmed from an interview with the first informant (CNK) who said: "The uploaded content is all activities related to Yehonala School programs, learning and activities." This is in line with the second informant (MAM) as the Head of Multimedia stating "the uploads on Yehonala school's Instagram are more of educational content because the accounts they manage are accounts that are engaged in the world of education". Every upload on Instagram social media uses a hashtag that shows the identity of Yehonala's school, namely \#yehonala \#yehocircle \#yeho \#yck \#yeho3yearsbundle. The use of hashtags is intended to accelerate and expand the dissemination of information. In addition to using special hashtags, Yehonala school also uses general hashtags such as \#batam \#bestschool \#qualityschool. Testimonials from parents also add value to the @ yehocircle account, of course, it will provide easy access to search traffic to the official Yehonala school account.

\section{Figure 2. Parent's Testimonial on Yehonala School's Instagram}

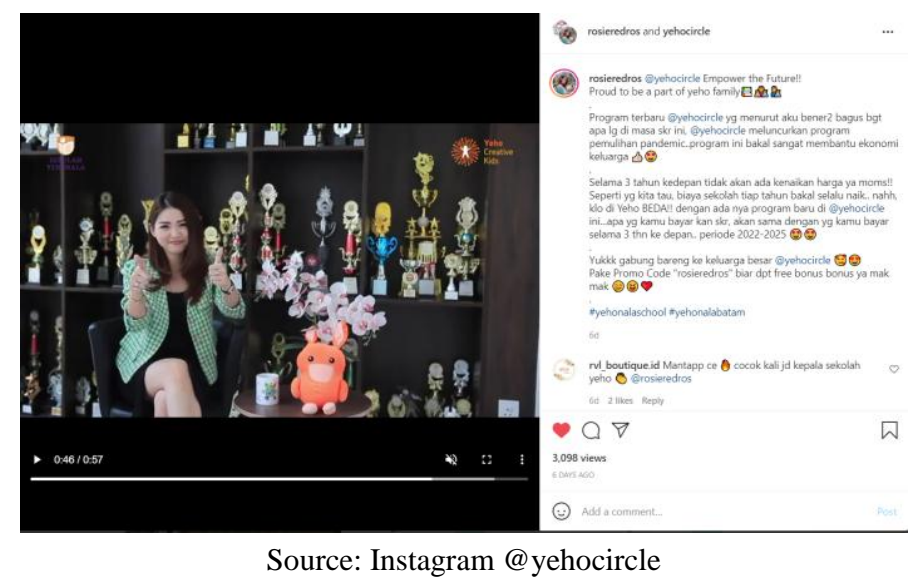

In terms of updating the page and story of the @yehocircle account, the agenda has been determined and does not demand the possibility of posting off the agenda. This information was obtained through an interview with the first informant $(\mathrm{CNK})$ : "There is an agenda. For example, today I want to make about a talent show, so make it about a talent show on social media. Now, like now, the New Student Admission (PSB) has become a publication on social 
media regarding registration and now marketing is intensively on social media.". During the new school year, every content uploaded to the @yehocircle account always provides information to the public, especially prospective parents. Parents who are outside Batam City also see the uploads on Yehonala's school account so that in the new school year many prospective students and students come from outside Batam City. This was stated by the second informant (MAM): "It's pretty good for those who come here, since we are diligent in publishing, since we consistently publish it. Even those from outside the city immediately apply."

Yehonala School's PR practitioners pay attention to certain hours to upload content on Instagram with the intention that the uploaded content can reach the public. This statement was confirmed by the statement from the first informant (CNK): "We also pay attention to the time of posting because Instagram has certain hours for posting so that many will pay attention. I have converted the posts that I want to post into one file and then send them to my superiors to be checked and provide information to my superiors that for seven days these photos or images will be posted on social media.". This statement is reinforced from previous research conducted by Amanda P. Santoso, et al. It is said that upload time (month and day) has a significant influence on social engagement on likes and comments (Santoso et al., 2017).

Figure 3. Content on Yehonala School's Instagram

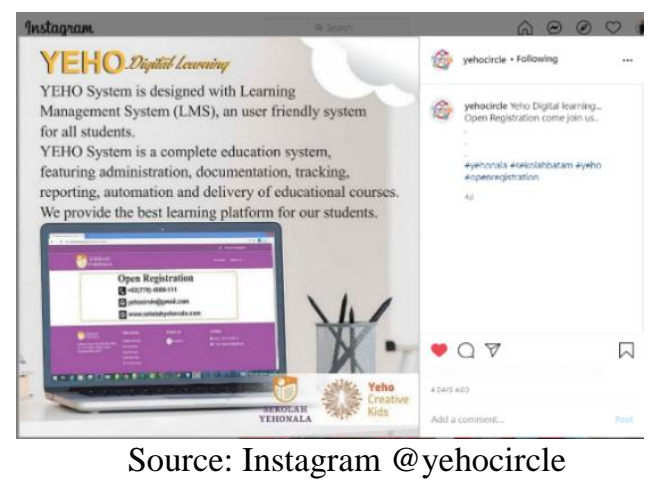

The two informants (CNK and MAM) said that any content that the Yehonala school PR practitioner wanted to upload to social media had first gone through a review process carried out by the school owner and the head of the foundation through a WhatsApp group that had been created previously and there was also a meeting to discuss discuss what content is relevant for the future. This was confirmed by the first informant (CNK): "Content must have an acc from the school owner and the Head of the Foundation via WAG".

In the content creation process it takes from one day to three days, the length of content creation is judged based on the difficulty of the design and also the content of the content faced by PR practitioners. The same statement was conveyed by the second informant (MAM) stating "Content that has been in ACC, will be processed, depending on the request and the level of difficulty of the design". If there is a request from the superior to complete the content within one day, the PR Practitioner and the Head of Multimedia will work together to complete it. The most frequently uploaded content on the @yehocircle account is educational content. Educational content gives the @yehocircle account an increase in followers on Instagram, this 
was revealed by a second informant (MAM): "For Instagram, we are more focused on educational content because we are at school. It seems that since the educational content we posted, the followers have increased.". After the content was uploaded, the PR practitioner and the Head of Multimedia continued to pay attention to the traffic flow and the number of accounts visiting the @yehocircle Instagram account. This was revealed by the second informant (MAM) "We pay attention to our followers, there is no effect on us posting this. It turned out that during this one week the number of followers increased quite a bit, because maybe people also wanted to know. What we post is knowledge that is rarely known by people, we are looking for something unique that if we don't learn it at school."

In addition, Yehonala school also opens opportunities for parents to send videos of children's learning activities to the homeroom teacher then the homeroom teacher sends the video to the school's Public Relations to be processed based on the school's video format which is then uploaded to the Yehonala school's official Instagram account. As stated by the first informant (CNK): "parents work well with us because we have a good relationship. For example, students are given assignments, the mother sends video to the teacher, then the teacher sends it to the media and the media edits and then posts it. We thank the parents for supporting everything from sending videos of their children dancing, singing, studying and creating stories tagged on Yeho's Instagram."

\section{The resulting reaction}

In using media in the network, especially social media, the Yehonala school PR feels that there are advantages and disadvantages in maintaining the image. The perceived advantage is that Instagram social media is more user-friendly, fast, easy to operate and free of charge unless there are special features provided by Instagram. The advantage of using social media is that it provides convenience and speed, because uploads containing videos and photos directly provide clear images compared to using conventional media. This was stated by the first informant (CNK) who said that: "The advantages are many, especially the ease and speed of updating, if social media is conveyed, starting from videos, photos, everything speaks." With the existence of social media, it can provide concrete evidence and make it easier for the Yehonala school to provide information at any time. While the perceived drawback is the existence of fake accounts created intentionally by irresponsible parties to spread information that is not in accordance with the truth. Therefore, the role of PR as a communication technician is really needed in terms of maintaining an image.

The first informant (CNK) said that, while using Instagram, there were no complaints from the public but received positive responses. This was stated directly by the first informant (CNK): "For complaints, no one is logged on to Instagram, but everyone is happy. For complaints, there's no way to go to Instagram anyway.". Although the Yehonala school's Instagram account received a positive response, the third informant (LD) said that there are still few people who know the existence of the Yehonala school, especially the public who do not have Instagram. This was revealed at the end of the interview with the third informant (LD): "Because very few people know about Yehonala. Yehonala has been around for a long time, but many don't know it." 
The challenge for Yehonala school PR practitioners when using Instagram is having difficulty determining what content to upload due to the many activities of students and the photos that must be selected starting from those sent by parents and also the results of homework documentation. This was conveyed by the first informant $(\mathrm{CNK})$ : "The challenge is that we are confused in finding content to post for two days and one post because there are so many activities and selecting photos is not easy because of so many, we must be confused about which post to post, what caption to use. what are you aiming for?"

In systems theory, it is said that the organization is a system in which there is an interaction between parts in its continuity. The system that is outside the organization is referred to as the environment so that between the organization and the environment exchanges occur. There are two systems in this theory, namely open and closed systems.

Open organizational systems use public relations practitioners in organizations to seek information about how well their organization's relationship with the public is, while closed organizational systems are organizations that do not seek to find the latest information so that all types of decision making are based on past experience or personal desires (Pahlevi, 2017). Findings in the field found that the role of Yehonala's school PR is only as a communication technician because various activities are based on technical communication skills, namely only creating content, posters to be uploaded on the media in the network and Public Relations practitioners are not involved in decision making or organizational policies and Yehonala's school homework is not directly related to the environment. All forms of information provided by stakeholders are provided to school owners, heads of education and homeroom teachers.

\section{CONCLUSION}

The role of Yehonala's school homework in maintaining the image as "The Best Learning Place for Children" is only as a communication technician as evidenced by three things, namely the use of social media, social media content and the resulting reactions. Of the four social media used by Yehonala school, Instagram is the media that is most used as a means to maintain image and promotion by uploading educational content, facilities and programs that support to maintain image. There is an agenda to upload content on Instagram so that information can be conveyed in a directed manner. Every content uploaded by a PR practitioner has been reviewed by the Yehonala school owner and the head of education. PR practitioners pay attention to special hours for uploading content so that content can reach the public. There are advantages and disadvantages in maintaining an image through social media. The perceived advantage is that Instagram social media is more user-friendly, fast, easy to operate and free of charge unless there are special features provided by Instagram. While the drawback is the existence of fake accounts that are used to spread information that is not in accordance with the truth.

The role of Yehonala's school PR, which is the most prominent of the four concepts of PR roles by Cutlip, Center and Broom, is the role of a communication technician. Because activities are based on technical communication skills, namely only creating content, posters to be uploaded on the media in the network and Public Relations practitioners are not involved in decision making or organizational policies and Yehonala school homework is not directly related to its 
environment. All forms of information provided by stakeholders are provided to school owners, heads of education and homeroom teachers.

Based on systems theory, Yehonala school PR practitioners do not get the freedom to interact with the public because they are not involved in managerial roles. Yehonala School is an organization, where the organization is a system in which there is an interaction between parts in its continuity. The system that is outside the organization is referred to as the environment so that between the organization and the environment exchanges occur. Exchanges do not go through PR practitioners but only through parents to school owners, heads of education and homeroom teachers. So that Yehonala school is categorized as a closed system based on systems theory because the role of public relations practitioners is not used as an information seeker between the organization and its environment. Suggestions for Yehonala school, should include the role of PR as a managerial so that more information can be obtained.

\section{REFERENCES}

Ardianto, E. (2018). Handbook of Public Relation (N. S. Nurbaya (ed.); Kelima). Simbiosa Rekatama Media.

Dida, S., Subekti, P., Lukman, S., \& Dewi, R. (2017). Corporate Public Relation (S. Dida, P. Subekti, S. Lukman, R. Dewi, \& F. A. A. Prastowo (ed.); 1 ed.). UNPAD Pres. http://prodihumas.fikom.unpad.ac.id/wp-content/uploads/2017/11/Buku-CorporatePR.pdf

Doni, rohma F. (2017). Perilaku Penggunaan Smartphone Pada Kalangan Remaja. Journal Speed Sentra Penelitian Engineering dan Edukasi, 9(2), 16-23. https://doi.org/10.1371/journal.pone.0028245

Etikan, I. (2016). Comparison of Convenience Sampling and Purposive Sampling. American Journal of Theoretical and Applied Statistics, 5(1), 1-4. https://doi.org/10.11648/j.ajtas.20160501.11

Febbyana, D. C. (2017). Pengaruh Konten Instagram Terhadap Minat Berkunjung Konsumen. Mm, 1-18. https://ejournal.ilkom.fisip-unmul.ac.id/site/?p=3785

Kemp, S. (2021). Digital 2021: Indonesia. DataReportal. https://datareportal.com/reports/digital-2021-indonesia

Kriyantono, R. (2014). Teknik Praktis Riset Komunkiasi (Gustiara Azmi (ed.); 7 ed., Vol. 7). Prenamedia Group.

Mahfuzhah, H., \& Anshari, A. (2018). Media Publikasi Humas Dalam Pendidikan. AlTanzim : Jurnal Manajemen Pendidikan Islam, 2(2), 137-149. https://doi.org/10.33650/al-tanzim.v2i2.395

Mania, S. (2008). Observasi Sebagai Alat Evaluasi Dalam Dunia Pendidikan Dan Pengajaran. Lentera Pendidikan : Jurnal Ilmu Tarbiyah dan Keguruan, 11(2), 220-233. https://doi.org/10.24252/lp.2008v11n2a7

Miles, M. B., \& Huberman, A. M. (1994). Qualitative Data Analysis (R. Holland (ed.); Second). SAGE Publications.

Pohan, Z. (2018). Peran Humas Public Relations Pada Bidang Pendidikan. Jurnal Sintesa, 
18(1), 103-110.

Purwanti, A. (2018). Corporate branding Sebagai Peran Public Relations PLN Bright Batam dalam Meningkatkan Pelayanan Publik. Jurnal Akrab Juara, 3(1), 61-71.

Rasyid, A. A., \& Purwanti, A. (2020). Pemanfaatan instagram oleh generasi milenial sebagai media bisnis online di kota batam. Intelektiva : Jurnalekonomi, Sosial \& Humaniora, 01(12), 1-8.

Santoso, A. P., Baihaqi, I., \& Persada, S. F. (2017). Santoso et al 2017. 6(1).

Satria, R., Supriyanto, A., Timan, A., \& Adha, M. A. (2019). Peningkatan mutu sekolah melalui manajemen hubungan masyarakat. Jurnal Akuntabilitas Manajemen Pendidikan, 7(2). https://doi.org/10.21831/amp.v7i2.26018

Suwendra, I. W. (2018). Metodologi Penelitian Kualitatif dalam Ilmu Sosial, Pendidikan, Kebudayaan, dan Keagamaan. In Metodologi Penelitian Kualitatif dalam Ilmu Sosial, Pendidikan, Kebudayaan, dan Keagamaan.

Wahyuni, P. A., \& Ernungtyas, N. F. (2020). Pemanfaatan Media Sosial dalam Public Relations di Sekolah Menengah Kejuruan. Jurnal Komunikasi Nusantara, 2(1), 10-16. https://doi.org/10.33366/jkn.v2i1.35 